\title{
teacher and learner perspectives on philosophical discussion - uncertainty as a challenge and opportunity
}

\author{
kerstin michalik ${ }^{1}$ \\ university of hamburg, Germany \\ orcid id: https://orcid.org/0000-0003-0258-7688
}

\begin{abstract}
We investigated teachers' and children's experiences of philosophy with children by analysing the content of interviews with primary school teachers and discussions with groups of primary school pupils. The results show that regular philosophy sessions with children can have an impact on teachers' view of themselves as educators, their approach to teaching and their personal development. From the children's point of view, the most important and meaningful aspect, aside from the content of philosophical discussion, was the opportunity to think together in an open-ended way. A key component of the collective construction of meaning was uncertainty, which is an integral feature of philosophical discussion. These findings link with the idea of "citizen as agent" in a variety of ways. Philosophising with children leads to a more collaborative and democratic teaching style, giving children the space to bring their own interests and activities to the discussion. This aligns with pupils' enjoyment of the openness and uncertainty of philosophical issues, their appreciation of the opportunity to engage with different ideas and viewpoints, and their willingness to rise to the challenge of revising their own positions and changing their thinking.
\end{abstract}

keywords: uncertainty; theory of education; philosophizing.

\section{perspectivas do ensinante e do aprendiz sobre a discussão filosófica - incerteza como desafio e oportunidade}

\section{resumo}

Investigamos as experiências de professorxs e crianças com a filosofia com crianças através da análise do conteúdo de entrevistas com professorxs da educação infantil e de discussões com grupos de alunos deste mesmo segmento. Os resultados mostram que sessões periódicas de filosofia com crianças podem impactar a visão dxs professorxs de si próprixs como educadores, sua abordagem de ensino e seu desenvolvimento pessoal. Do ponto de vista das crianças, o aspecto mais importante e significativo, além do conteúdo da discussão filosófica, era a oportunidade de pensarem juntas de forma não-definitiva. Um componente essencial da construção de sentido coletiva foi a incerteza, que é um aspecto integral da discussão filosófica. Essas descobertas se relacionam com a ideia de um "cidadão agente" de diversas maneiras. Filosofar com as crianças leva a um estilo de ensino mais colaborativo e democrático, que dá a elas espaço para trazerem para a discussão seus próprios interesses e atividades. Isto se alinha com a satisfação dos alunos em relação à abertura da incerteza das questões filosóficas, a valorização da oportunidade de se envolver com diferentes ideias e pontos de vista e seu desejo de enfrentar o desafio de rever suas próprias posições e mudar seu pensamento.

palavras-chave: incerteza; teoria da educação; filosofar.

${ }^{1}$ E-mail: Kerstin.Michalik@uni-hamburg.de 
teacher and learner perspectives on philosophical discussion - uncertainty as a challenge and opportunity

\section{perspectivas de docentes y alumnos sobre la discusión filosófica: la incertidumbre co- mo un desafío y una oportunidad}

\section{resumen}

Investigamos las experiencias de maestros en filosofía con niñas y niños a través del análisis de contenido de entrevistas con maestros de la educación infantil y de discusiones con grupos de alumnos de este mismo nivel de enseñanza. Los resultados muestran que sesiones regulares de filosofía con niñas y niños pueden tener un impacto en la visión de los maestras de sí propias como educadores, su abordaje de la enseñanza y su desarrollo personal. Desde el punto de vista de niñas y niños, el aspecto más importante y significativo, aparte del contenido de la discusión filosófica, fue la oportunidad de pensar juntos de manera abierta. Un componente clave de la construcción colectiva del significado fue la incertidumbre, que es una característica integral de la discusión filosófica. Estos hallazgos se relacionan con la idea de "ciudadano como agente" de varias maneras. Filosofar con niñas y niños conduce a un estilo de enseñanza más colaborativo y democrático, dando a niñas y niños espacio para llevar sus propios intereses y actividades a la discusión. Esto se alinea con el disfrute que sienten por la apertura y la incertidumbre de los problemas filosóficos, su apreciación de la oportunidad de participar con diferentes ideas y puntos de vista, y su disposición a afrontar el desafío de revisar sus propias posiciones y cambiar su forma de pensar.

palabras clave: incertidumbre; teoría de la educación; filosofar. 
teacher and learner perspectives on philosophical discussion - uncertainty as a challenge and opportunity

\section{introduction}

What is the point of doing philosophy, according to teachers? What changes and developments do they observe in children, and in themselves? What problems and challenges do they face? What do children think is particularly important about philosophy sessions, and how is this different from other teaching and learning contexts? Studying the subjective experiences of teachers and children, how they perceive issues, construct meaning and evaluate sessions, does not, as a methodology, seek to establish an objective view of events; instead, it aims to capture participants' experience. Examining the experience of philosophical discussion from the point of view of those involved - teachers and children - is an important addition to the hitherto predominantly quantitative analysis of the impact of philosophy with children.

This approach to research has only recently been pursued in any depth (cf. Barrow, 2015; Scholl, 2014; Scholl, Nichols \& Burgh, 2014; 2016; Topping \& Trickey 2007; Gorard, Siddiqui \& See, 2015; Siddiqui, Gorard \& See, 2017) and highlights aspects of philosophy with children with which standardised quantitative methods cannot engage, or with which they can at best engage only partially. The results are relevant both to the practical question of how to make a success of philosophy in schools and classrooms and to professionalisation and childhood studies research. Moreover, reviewing philosophy sessions from the children's perspective places children centre stage and gives them a voice. It takes their perceptions, opinions and evaluations seriously and as an approach it is therefore very much in keeping with the basic principles of philosophy with children.

\section{1. uncertainty: philosophical, pedagogical and psychological aspects}

Uncertainty is a central feature of philosophy with children. It deals with open questions, philosophical questions, to which there are no definitive answers. Uncertainty is integral to philosophical thinking, and to philosophising as an activity, which also involves multiperspective thinking and a constructive approach 
teacher and learner perspectives on philosophical discussion - uncertainty as a challenge and opportunity

to ambiguity. How to deal with the openness of philosophical questions and the ambiguity of potential answers is one of the particular challenges of philosophical discussion. This applies both to the children who are doing the philosophising and to the teachers who are leading the discussion. Philosophical discussion is in tension with the aims of classroom teaching and the frameworks in which it operates. These have certainty at their core, in the form of "right" answers and teachers' role as superior imparters of knowledge. Our evaluation of the interviews therefore focused particularly on how the interviewees and children's group discussions reacted to the "uncertain" aspects of the sessions.

Uncertainty, or ambiguity, is a construct that is of increasing importance for a range of academic disciplines as well as in a social context. The term has no standardised usage; different concepts - uncertainty, ambiguity, insecureness - are used in different situations. The concept is traditionally rooted in mathematics, probability theory and philosophy. In psychology, uncertainty or ambiguity tolerance refers to people's ability to deal with new and unfamiliar situations (Jeschke, 2013). Uncertainty is a limiting factor in epistemology, which involves critical reflection on the finite nature and provisionality of scientific knowledge. Uncertainty has dual relevance for education: on the one hand, it is an important constituent of deep learning, and of teaching and learning for personal development; on the other, dealing productively with uncertainty in the context of current social developments is an increasing important educational goal.

The concept of uncertainty takes on particular significance for educational science in the context of transformative theories of learning. For deeper processes of teaching and learning, processes that go beyond the mere acquisition of knowledge and skills, it calls for pupils to challenge and change how they see the world. Koller draws on Wilhelm von Humboldt's ideas, defining education as "transformation of the relationship with the self and the world through engagement with new issues" (Koller, 2012, p. 16). On this basis, learning consists in the construction of new structures for perceiving, interpreting and tackling problems by engaging with new issues. The concept of education as transformational highlights the potential for teaching and learning to be characterised by crisis and con- 
flict. Students change the way they relate to themselves and the world by engaging with new and unfamiliar challenges that cannot be accommodated within their previous world view, and which therefore require them to broaden or overhaul their perceptions, thinking and actions.

Philosophising puts engagement with open questions and uncertain answers centre stage. Philosophical discussion makes you conscious of your relationships with yourself and the world, makes those relationships public and asks you to reflect on them as you confront other ways of thinking and points of view. Philosophical discussion represents a challenge and an opportunity, to broaden or even change your own way of thinking. It is therefore reasonable to infer that philosophising with children creates space for deep learning processes and multiperspective thinking (Michalik, 2015). Philosophising also sparks productive engagement with uncertainty (Helzel, Michalik, 2015), which is relevant not only for specific teaching and learning processes but also for the social goals of school and education. In a world that is increasingly characterised by uncertainty, instability and the openness of values, it is increasingly important for individuals to be able to deal openly and constructively with uncertainty - to have high uncertainty tolerance, as psychologists would put it.

\section{2. note on methodology}

Since the aims of the study were to take a closer look at certain aspects of philosophy with children on the one hand and on the other to allow teachers the space to speak about issues that concerned them and were relevant to them (cf. Flick, 2016, 203f.), the approach taken was to collect data from teachers in the form of semi-structured, guided interviews. The data were derived from two surveys (Michalik, 2012, Haller 2015)², which interviewed two groups, one of five teachers and one of six, giving a total of eleven. The teachers came predominantly from Hamburg and were interviewed for between 20 and 40 minutes. The recordings were transcribed and then coded and classified on the basis of Mayring's qualitative content analysis (2015) as part of an inductive approach aimed at drawing out

\footnotetext{
${ }^{2}$ Data from Michalik 2012 will henceforward be referred to as Mi and data from Haller as Ha.
} 
teacher and learner perspectives on philosophical discussion - uncertainty as a challenge and opportunity

key themes and issues. The teachers involved were primary school teachers, special needs teachers and social education workers aged between 28 and 66, and all had experience of philosophy with children, having incorporated philosophical enquiry into the teaching of other subjects (Art, R.E., Maths, German and Humanities), or provided whole day or elective philosophy sessions in the context of remedial teaching.

In parallel with teacher interviews, group discussions were held at a Hamburg primary school with a total of 70 children from three different groups of mixed-age learners (Years 1-3, i.e. 6-9 years of age, and Years 4-6, i.e. 10-12 years of age) (Michalik, 2012). All three groups of learners had regular whole-group philosophy sessions with their teachers for a period of between six months and two years prior to the discussions. A total of five group discussions were held, each with a group of 10-12 children. Discussions were videotaped, transcribed and coded and classified by topic using Mayring's inductive content analysis method.

\section{3. teachers' experience of philosophy with children}

The issues raised in the teacher interviews were so diverse that it is only possible to consider a small selection of them in depth, namely comments on whether the teachers perceived changes or developments in the children or in themselves that in their view could be traced back to the regular philosophy sessions. The issues explored below emerged in the answers given by almost all teachers.

\section{1 perception of children by teachers}

Many teachers report that the philosophy sessions changed their perception of the children and led them to take a different attitude to their pupils. Teachers' surprise at the children's ability to think, the depth of their thought and the profound nature of the questions they raised were often cited as the triggers for a change of perspective. "I was astonished how seriously and deeply the children were able to think about existential questions." (Mi, E17). "I was surprised when I realised that the children had a lot to say, and that they were actually able to think 
deeply about a wide range of issues, and were able to do so as a group." (Mi, C38). "Well, I was amazed how much they already understood about the world. It's incredible how they interpret things." (Ha, AVI, 50).

Changes in perception of children's ability and potential goes hand-in-hand with a fresh appreciation of and increased interest in how children are thinking, because they "think much more freely than we do as adults if they have the confidence and are given the opportunity." (Ha, AIX, 34). One teacher describes herself as "very curious to find out what drives children, what children know, what kind of picture children have of the world. [...] Whether, as usual, their thinking runs along different lines. And it's not only the children who are getting something from this - I am too, a very great deal." (Ha, AV, 8).

As well as changing their perception of children's thinking skills in general, teachers also report that they have broadened their perspective and revised their opinion of individual children, because such children have come across completely differently than in conventional lessons. This is often the case for children who tend to be quiet and reserved. "And I'm always surprised by how quickly children who are normally very quiet [...] participate in philosophical discussion and share their thoughts." (Mi, C100, A84ff). This also applies to children with behavioural problems or whose learning outcomes lead them to be perceived as weaker. "The children who really get their teeth into philosophy are completely different - they are often the ones who have real difficulties with reading, writing and maths. Philosophy brings out different strengths." (Mi C154). "Children with behavioural difficulties really threw themselves into this kind of discussion." (Mi, E19).

Doing philosophy together not only changed teachers' perceptions of children. Teachers also felt that the children perceived and valued them differently, and this was "to do with the attitude you, as an adult, have towards children in these kinds of sessions." (Ha, AVI, 28). Another reason may well be the closer interpersonal contact many teachers said they had with the children as a result of doing regular philosophy sessions together, and which had an impact on their teaching. 
teacher and learner perspectives on philosophical discussion - uncertainty as a challenge and opportunity

\section{2 impact on pedagogic practice and the role of the teacher}

The changes in many teachers' perception of children's thinking skills and ideas has implications for pedagogical practice and for how teachers view themselves as professionals. "I take a completely different approach to discussions than I did ten years ago, even with young children - I simply value children's thought processes more highly." (Ha, AIV, 27). Other teachers report that they have developed better listening skills, and above all that they have learned restraint. "I had to learn to hold back, and that was a very important step for me, not to be constantly leading and guiding the discussion. [...] And I really had to work at it - I didn't know how to do it." (Mi, B33).

This kind of attitudinal change is also evident in changes to lesson planning, where children's issues and interests outside of philosophy are increasingly used as the basis for sessions. "Before, if you were tackling the topic of puberty, for instance, you'd have decided in advance what the content of the discussion with the children would be, whereas now you turn it round and ask, what are you interested in? What goes through your mind when you think about this topic? So you're working more on the basis of the children's questions, and what interests them." (Mi, A247ff). "When I opened the questions box for the first time with a group of learners, I was stunned by the fantastic questions they had come up with. And that was the moment when I said to myself, you don't have to turn up to lessons with umpteen pre-prepared questions [...], you can discuss questions that the children have thought up themselves. And that's what student-centred, autonomous, individualised learning is all about." (Mi, D138).

Teachers and pupils doing regular philosophy sessions together also has the potential to transform teachers' understanding of their role by reducing the power gap between pupils and teachers. What teachers particularly value about philosophy sessions is the depth and intensity of the discussion and the authentic "dialogue of equals" (Mi, B33), in which the traditional role of the teacher as knowledge provider is suspended. "What happens of course, is that your image as the teacher changes [...], because you step out of the role of being the provider of answers $[\ldots]$ and you and the children all have to come to terms with the fact that 
you aren't providing them [...]." (Ha, AIX, 19). "I keep being surprised by the issues groups are interested in, and then having to reconsider them myself [...] and there aren't any answers to the questions that they raise. Then you think things through with the children, and you have to think like a child again, or at least try to. And to follow their train of thought, just as they try to follow mine." (Ha, AX, 44). Other teachers speak of the philosophical community of inquiry as a "band of equals" (Ha, AVIII, 8) or of the new role of the teacher as a fellow traveller with children as they learn (Ha, AVI, 19).

These kinds of statements indicate a transformation in the relationships between teachers and children. They arise to a large extent from the range of uncertainties that are integral to philosophical discussion.

\section{3 uncertainty as challenge and opportunity}

Coping with uncertainty in an epistemic as well as a pedagogical sense is a continually recurring theme, and relates to uncertainty in a number of forms, namely

- philosophical issues and the range of possible answers to philosophical questions

- the open-endedness of philosophical questions and research in general and

- the unplanability of philosophical discussion and the loss of control that this means for teachers.

"Of course, you have to be well prepared to be able to lead this kind of open discussion. And yes, you are entering into a kind of uncertainty. Because of course you don't know where the lesson will actually end up." (Ha, AVI, 52f).

“You can't plan or predict these kinds of discussions [...] and that's a challenge. It's to do with your attitude, how you see yourself as a teacher, whether you can live with the fact that maybe there are things you don't know, either" (Mi, EK 319).

Teachers are aware that the openness of philosophical questions and research can present a particular challenge to the traditional role of the teacher and the expectations and self-image that go along with that: 
teacher and learner perspectives on philosophical discussion - uncertainty as a challenge and opportunity

"But that's how you feel as a teacher, that you always have to have everything under control. So the first thing you have to do really is accept that you can't direct it all, and just go with it. Then the children will actually come up with the questions." (Mi, C15).

"You're kind of expected to be a perfectionist, really, you always have to be meticulously prepared and get everything right and not make any mistakes. It's not easy to be that way and then become quite free and open." (Mi, EB338).

"Sometimes you hear people object that it's difficult to do philosophy with children at school because as a teacher, it puts you in a position where you don't know it all, either." (Mi, E14).

Teachers who philosophise with children confront traditional expectations of their role head-on, for example by emphasising that dealing productively with lack of knowledge is an important part of the learning process, and that teachers also act as role models in this regard: "It's ok to make mistakes and not know things, and that has to start with me." (Mi, LG 214).

The uncertainty and indeterminacy of results and the open way in which philosophical discussion is conducted are primarily seen as an opportunity:

"Rather than being focused on results, you have to really enter into it and accept that it could go in directions that you weren't expecting. But this can also be very rewarding." (Ha, VIII, 41). The open nature of the discussion can, for instance, lead the children to make links with other subjects or with experiences from their own lives. "They don't categorise their experience by subject, and this allows them to engage with it in a more flexible way." (Mi, E17).

The overwhelming view that the openness of philosophical inquiry and research with children is an advantage rather than a problem is also demonstrated by teacher statements on the relevance of philosophy with children for their own lives and for their personal development.

\section{4 impact on teachers' own learning and personal lives}

The vast majority of teachers believe that philosophy with children has significantly enriched their personal and professional lives. Teachers place particular 
emphasis on the broadening of their horizons and changes in their thinking, triggered by the inherent challenges of philosophical enquiry and more particularly by their exchanges with the children and the children's view of the world. "It's always a great gift for me at a personal level to do philosophy with children, because I see the world through the children's eyes and get their perspective on it. And that always reminds me of what life's all about. [...] What are the fundamental questions?" (Ha, AVI, 35). "I'm thinking about things that I haven't thought about before. [...] I'm taking a completely new and different interest in things. So my perspective really has broadened" (Ha, AV, 8). "I often think about the world in a completely different way, or suddenly see the world with different eyes" (Mi, LG118). Philosophy sessions "strengthen your perception, they make you more aware of your attitude to social issues." (Mi, C39). "Philosophy is enriching my life and my professional practice in a new way [...] It's a kind of oasis in the middle of school." (Ha, AVI, 19, 28).

Teacher observations on the effects of philosophy sessions and the changes in the children broadly correspond with the results of other research studies (cf. Michalik, 2018). The following effects were frequently noted:

- improved communication skills and behaviour in discussions, including in cases of conflict

- generally more respectful behaviour by the children towards each other

- improvements in children's ability to reflect, which were also evident in changes to how the children approached tasks in other lessons, such as Maths

- a more critical approach and changes to the way children approach issues

- greater self-confidence and greater awareness of themselves as learners

However, the interviews also make clear that some teachers believe philosophy is not suited to all children, that philosophy sessions can also be demanding for children and that some children are not interested in philosophical enquiry and debate, or are not in a position to get involved in it. This is an interesting and important issue and merits further consideration. 
teacher and learner perspectives on philosophical discussion - uncertainty as a challenge and opportunity

The results of the teacher interviews are in large part in line with existing research findings, indicating that from the point of view of teachers, philosophy with children can lead to changes in teachers' perception of children, and therefore their attitude to them. That in turn has an impact on their pedagogical practice, including in other subjects. The trigger or driver for such changes is repeatedly identified as "surprise" or "astonishment" (Gorad, Siddiqui \& See 2015, p. 27; Pfeiffer 2013, p. 655; Topping \& Trickey 2007, p. 32) at children's thoughts and thinking skills. Scholl, Nicholls and Burgh, who interviewed teachers in Australia about the impact of philosophy sessions on their own subject sessions, talk of "experiences of dissonance" (Scholl/ Nichols/Burgh 2016, p. 437) that lead teachers to reflect on the way they have been seeing themselves and their role as teachers. This leads to changes in the way they relate to and interact with children in the classroom, characterised as allowing more space for children's questions and interests, greater autonomy and lower levels of control on learning, and much more collaborative, interactive, dialogic and democratic teaching (Scholl, 2014, p. 93ff., 96ff.; Gorard et al. 2015, p. 28; Siddiqui, Gorard \& See 2017, p. 31; Scholl, Nichols \& Burgh 2014, p. 246, Barrow, 2014, p. 6). Such changes in teaching styles are accompanied by improved relationships with pupils, and better understanding of them and of their perspectives on the world (Jenkins, 1986, p. 36; Gorard et al. 2015, p. 27; Siddiqui et al. 2017, p. 31; Scholl, 2014, p. 100; Pfeiffer, 2013, p. 654).

Scholl, Nichols and Burgh identify a process of change that they describe as the "pedagogical transformation" of teachers, based on the increased ability of teachers to reflect on their own pedagogic practice (Scholl, 2014, pp. 89, 93), and that can be traced back largely to the process of doing philosophy with children. As part of the community of philosophical inquiry, teachers also benefit from the collective thinking process and the originality of the children's thought. Teaching and learning become two-way processes, and generate space for reflection and the transformation of paradigms (Scholl, 2014, p. 100, Scholl, Nichols \& Burgh 2016, p. 439). This also changes the "epistemic authority" of teachers (Barrow, 2015, p. 6) in favour of more equitable and democratic forms of learning and interaction. 
When asked about the conditions required to make a success of philosophy in schools, many teachers voiced criticism of the school system. Amongst other things, they mentioned time constraints, and organisational structures that were insufficiently geared towards promoting independence of thought and individual development in children due to a focus on homogeneous service standards. Lack of support from colleagues and management was also cited: philosophy was frequently categorised by them as a pleasant but pointless pastime that there was no time to include in lessons or integrate with the general demands of running a school. Though it is not possible here to look more closely at the opportunities for, and problems with, incorporating philosophy into lessons, this would be a useful starting point for further research.

\section{4. children's experiences with/evaluation of philosophy sessions}

The group discussions with children focused on the issue of what the children thought was good or less good about doing philosophy, what the differences were compared with the lessons they usually had, and whether anything had changed as a result of the philosophy sessions.

Two main points arose from the group discussions that it is worth rehearsing here. What the children particularly liked about philosophy sessions, and what distinguished them from other teaching and learning situations, were the subject matter and the process of thinking together; it was philosophy as an activity that was paramount for the children in this context. The large majority of children expressed very positive views about their experience of philosophy sessions. Only a few children stated that doing philosophy could also be boring sometimes, if the topic was less interesting or the discussion went on too long.

\section{1 content of philosophy sessions}

In terms of content, the children frequently said that doing philosophy enabled them to discover new and exciting things about "life" and "the world". Philosophy is obviously different from other subjects in the eyes of the children, because in addition to specific subject knowledge, it offers a more comprehensive 
teacher and learner perspectives on philosophical discussion - uncertainty as a challenge and opportunity

approach to the world. "Now I know more about life and the world, about the whole world somehow as well." (M2. 7.40). "You learn things about the whole world in philosophy - not just how to do maths problems or some facts about animals, but proper things about the whole world." (M2. 8.28). "I'm completely different when I come out than when I went in [...]. I learn much more then, because it's very important to know something about the world, too, that's why I store it all up in my head." (M1. 10.16). "Well, you just have more general knowledge afterwards." (K1.15.22)

Openness to a range of issues and also to issues that were important to specific individuals were also cited as a difference from other lessons. "The fact that you can actually talk about anything, and that you can say anything that comes into your head about the topic." (K2. 12.05).

Philosophical discussion clearly creates connections with the world outside the classroom, with the world children live in and with the children themselves. This is also evident in the fact that the children see philosophy sessions as a space where they have the right to express and discuss their opinions freely, and they value that. "I think it's good that you can say what you think." (K2. 3.10). "I like that we can discuss things." (K1.18.02). "You're not forced to do anything and you can give your own opinion." (K1.18.02). Philosophy provides the freedom and the opportunity for children to contribute their own ideas and express their point of view, and for the children this is one of the key differences from their usual lessons.

A particularly positive aspect for the children is that there are no definitive answers and so the outcome of discussions is not prejudged. "I think it's good that no opinions are wrong and none are right, either. So you could see things one way, but you could see them the other way as well." (B1. 2.04). "I think it's good that there isn't any right or wrong." (K2. 14.48). The openness and uncertainty of philosophical questions and discussion topics is not seen as a problem by the majority of children; rather, this is an especially positive aspect of philosophy sessions. Thinking about an issue together challenges children's own thought processes as well as developing their individual opinions and viewpoints. 


\section{2 the process of doing philosophy together}

The children mention the nature of philosophical discussion even more frequently than the content of philosophy sessions, and differentiate it from other, more conventional, modes of interaction in lessons. "It's a proper conversation, not like someone putting their hand up and saying something, then the teacher saying something, then the next person putting their hand up and saying something else - it's great." (K1.3.35). "Doing philosophy isn't like other lessons, where one person always puts their hand up and says something and then the teacher says something and then everyone has to work. In philosophy, you can say what you think, it's more open." (K1.3.26).

\subsection{1 exchanging opinions and ideas}

What makes philosophy particularly attractive is not only the opportunity to voice your own opinion but more importantly the exchange of views and ideas and the collective negotiation of meaning and significance. "I think you learn something about the others too, but that benefits you as well, you get to know the others and you can understand what they think." (K1. 11.9). "When you do philosophy, you find out what other people think, and you can understand them better." (K1. 10.16).

\subsection{2 challenging children's own ideas}

Even more than getting to know each other, philosophical discussion challenges children's ideas and points of view. The children explicitly view the whole process of doing philosophy as an opportunity to broaden or modify their own thinking. "I also think it's good because you can be influenced by other children and then think about your opinion, which may not be quite right, because then other people might say something that you have to think about some more." (K2. 1.10). “Well, I also think it's great when someone says, that's right and someone else says, well maybe not. Then you have to think again. I like that - I think it's good." (B1. 3.06). "You change your opinion every time you talk about something, not completely, but you think about it and think, hmm, yes, it could be like this or 
teacher and learner perspectives on philosophical discussion - uncertainty as a challenge and opportunity

like that." (K1. 12.64). "I often change my opinion when I hear other people's opinions and their reasons [...] but the reasons are important." (K1. 16.09).

Many comments relate to the openness of the process and the variety of opinions and perspectives in philosophical discussion, where uncertainty as to the "right" answer is predominantly seen as an interesting challenge to reconsider and differentiate one's own position. The fact that uncertainty can be demanding and difficult is rarely mentioned, and if it is, this is generally by younger children. "I don't really like that nothing is right, because then you can't say anything right." (B1. 5.05). "If one person says something's right and another says no, you can't just agree with them both and that's very difficult." (B1. 6.53).

\subsection{3 changes in children's own thinking}

The children have interesting things to say about whether philosophical discussion has changed anything about them. Here, they often identify changes in their way of thinking. "Well, I think that I think a bit more now about different [other] things." (K2. 5.14). "Well, when someone says something, you think things through more than you used to." (K1. 3.17). "I'm better at thinking things through now - I don't know why, but I think it might be from doing philosophy." (B1. 13.49). "We think about more things, you think more carefully when you do it as a group." (K2. 3.11).

The group discussions are a striking illustration of children's willingness and ability to get involved with collective reflection, and to view the fascinating variety of opinions and perspectives, and the uncertainty in relation to the results of philosophical enquiry and research, as a positive experience and as a challenge to develop their own thinking and reflect further. Exchanging views with other children, and the collective search for meaning and significance, seem to be of particular help when it comes to dealing productively with uncertainty. "If there are different opinions, I think again, is that right? Then I just say it and we all think about it again together." (K2. 5.14).

Several studies where children were asked to provide subjective evaluation, either through individual interviews or on the basis of standardised question- 
naires (some of which offer the option of providing open responses), confirm the results of the group discussions. Aside from the content of sessions, the factor that sets philosophy sessions apart for pupils and makes them especially appealing is the process of thinking things through together, the opportunity to voice one's opinion freely and exchange diverse views and opinions; and the associated opportunity to change one's own thinking and develop it further (Barrow 2015, p. 10ff., Gorard et al. 2015, p. 27; Siddiqui et al. 2017, p. 33, Fair et al. 2015, p. 29; Topping \& Trickey 2007, p. 13ff., Pàlsson, 1996, p. 27). The children's comments present philosophy as a dialogic, participatory and democratic process, in which the variety of perspectives and the uncertainty about possible answers plays a particularly productive role. These results are confirmed by Helzel's empirical research into the development of a class of first graders who did philosophy for a year. According to Helze, discursive engagement with uncertainty leads to creative thought processes in which children make tentative, hypothetical attempts at exploration that show the relationship between the subject and the world is changing: "The moment of uncertainty is a key trigger for creative intellectual engagement that opens up space for personal development within teaching and learning processes." (Helzel, 2018, p. 265).

\section{5. conclusion - the transformative role of uncertainty for teaching and learning}

Examination of the subjective views of those involved with philosophical discussion, namely teachers and children, reveals that philosophy has the potential to help teaching, learning, education and school development become a more dialogic, participatory and democratic collective experience.

The results show that by transforming teachers' ideas about teaching and the way they deal with pupils, regular philosophy sessions can have far-reaching implications for their understanding of themselves as educators and for their pedagogical practice. This has an impact on both their personal and professional development. From the children's point of view it is clear that, in addition to the content of philosophical discussion, a key factor is the process of thinking things 
teacher and learner perspectives on philosophical discussion - uncertainty as a challenge and opportunity

through together, the way exchanging ideas enables them to examine and expand their own position.

The uncertainty that is integral both to the process and the outcome of philosophical discussion is characterised by children and teachers as a unique opportunity to change their perspectives and attitudes and to broaden their horizons. This represents a particular challenge for teachers, because this kind of collaborative teaching and learning is in tension with the role of the teacher and with conventional concepts of teaching; this may be one of the reasons philosophy with children and young people has yet to gain much traction in schools.

However, as the results of the study show, class philosophy sessions could help to relativise certain antinomies in teaching. Building on Kant's fundamental antinomy of education, "How am I to develop the sense of freedom in spite of the restraint?" (Kant, 1803), Helsper formulates a range of antinomies. Two of these are particularly relevant for philosophical discussion. The first is the "symmetry antinomy" (Helsper 2001, p. 82), according to which the relationship between teachers and pupils is fundamentally unequal because the teacher holds the epistemological power and has sovereignty of interpretation. As has been demonstrated, philosophical discussion weakens this structure because philosophical questions are also open for the teacher and the results of philosophical questioning and investigation are equally uncertain for all participants in the discussion.

A related second antinomy describes the tension between subsumption and reconstruction, or unity vs. difference. According to Helsper, an increasing lack of knowledge, or an increasing awareness of our fundamental lack of knowledge, is also linked with the advancement of modern science; differentiation and pluralism are simultaneously linked with the generalisation and universalisation of different phenomena. This tension is also fundamental to schools. Schools introduce adolescents to differentiation, relativisation and pluralisation on the one hand, but simultaneously have a tendency to homogenise. This, says Helsper, is evident in the way they generalise adolescents, turning them into abstract "pupils" to whom academic content is imparted instead of introducing them to openness and uncertainty (Helsper, 1996, p. 541 f.). Helsper stresses that if pupils were introduced to 
openness and uncertainty, it would have to be done in such a way that it did not generate increased fear of uncertainty, since this could lead them to close their minds in an anti-modernist manner (ibid, p. 543).

Openness and uncertainty are philosophy's home turf. As the results of discussion with the children show, having their own thinking questioned and challenged as part of an open and uncertain philosophical process was what made philosophy particularly enjoyable for them. In this sense, doing philosophy has shown itself to be an appropriate mechanism for helping children to develop an approach to openness and uncertainty that is free of anxiety.

It would be interesting for future research to investigate the conditions for running successful philosophy programmes in schools, from the point of view both of children and of teachers, and in particular to look more closely at the different manifestations of uncertainty and its impact on, and potential contribution to, learning and school life in general.

\section{references}

Barrow, W. (2015). „I think she's learnt how to sort of let the class speak“. An exploratory study of children's perspectives on P4C as participatory pedagogy. In Thinking skills and creativity, 17, p. 76-87.

Fair, F., et al. (2015). Socrates in the Schools from Scotland to Texas. Replication a study on the effects of a Philosophy for Children program. In Journal of Philosophy in Schools, 2/1, p. 18-37.

Flick, Uwe (2016). Qualitative Sozialforschung. Eine Einführung. 7th Edition. Reinbek bei Hamburg.

Gaparatou, R. \& Erganzaki, M. (2015). Stundents' Views about Their Participation in a Philosophy Program. In Creative Education, 6, p. 726-737.

Gorard, S., Siddiqui, N., \& See, B. H. (2015). Philosophy for Children. Evaluation Report and Executive Summary. School of Education. Durham University.

Haller, T. (2015). Philosophieren mit Kindern im Fachunterricht. Eine empirische Untersuchung zu Erfahrungen und Einstellungen von Lehrerinnen und Lehrern. Masterarbeit im Studiengang Lehramt Primar- und Sekundarstufe. Universität Hamburg.

Helsper, W. (1996). Antinomien des Lehrerhandelns in modernisierten pädagogischen Kulturen. Paradoxe Verwendungsweisen von Autonomie und Selbstverantwortlichkeit. In A. Combe, W. Helsper (Ed.). Pädagogische Professionalität. Untersuchungen zum Typus pädagogischen Handelns, p. 521-569.

Helsper, W. (2001). Antinomien des Lehrerhandelns - Anfragen an die Bildungsgangdidaktik. In U. Hericks/J. Keuffer/H.-Ch. Kräft/I. Kunze (Ed.). Bildungsgangdidaktik. Perspektiven für Fachunterricht und Lehrerbildung. Opladen.

Helzel, G. (2018). Kindliche Entwicklungsprozesse beim Philosophieren. Eine empirische Studie zu Ungewissheit und Mehrperspektivität. Opladen, Berlin, Toronto. 
teacher and learner perspectives on philosophical discussion - uncertainty as a challenge and opportunity

Helzel, G./Michalik, K. (2015). Kindliche Entwicklungsprozesse beim Philosophieren mit Kindern. Eine empirische Untersuchung $\mathrm{zu}$ Mehr-Perspektivität und Ungewissheitstoleranz. In: H.-J. Fischer/H. Giest/K. Michalik (Ed.): Bildung im und durch Sachunterricht. Bad Heilbrunn, p. 189-196.

Jenkins, J. (1986). Philosophy for Children Programme at a Gloucestershire Cemprehensive School in Great Britain. In Thinking. The Journal of Philosphy for Children, 6, 3, p. 33-37.

Jeschke, S. (Ed.) (2013). Exploring Uncertainty. Ungewissheit und Unsicherheit im interdisziplinären Diskurs. Wiesbaden.

Koller, H.C. (2012): Bildung anders denken. Einführung in die Theorie transformatorischer Bildungsprozesse. Stuttgart.

Mayring, P. (2015). Qualitative Inhaltsanalyse. Grundlagen und Techniken. 12., revised edition. Weinheim und Basel. Beltz.

Michalik, K. (2012). Interviews mit Lehrkräften und Gruppendiskussionen mit Kindern zu Wahrnehmungen und Bewertungen des Philosophierens mit Kindern. Forschungsprojekt an der Fakultät für Erziehungswissenschaft der Universität Hamburg.

Michalik, Kerstin (2015): Philosophische Gespräche mit Kindern als Medium für Bildungsprozesse im Sachunterricht. In Bildung im und durch Sachunterricht. In H.-J. Fischer/H. Giest/K. Michalik. Bad Heilbrunn. p. 175 - 182.

Michalik, K. (2018). Empirische Forschung zu Wirkungen philosophischer Gespräche mit Kindern. In. H. de Boer, K. Michalik (Ed.). Philosophieren mit Kindern - Forschungszugänge und -perspektiven. Opladen, Berlin, Toronto, p. 13-32.

Pálsson, H. (1996). We Think More than Before about Others and their Opinions. An Evaluation Report from Iceland. In. Thinking and Reasoning 12, p. 24-28.

Pfeiffer, S. (2013). Das Unterrichtsfach Philosophieren mit Kinder in MecklenburgVorpommern. In Pädagogische Rundschau 67, 6, p. 651-669.

Scholl, R. (2014). „Inside-out Pedagogy“. Theorising Pedagogical Transformation through Teaching Philosophy. In Australian Journal of Teaching Philosophy, 39/6), p. 89-106.

Siddiqui, N., Gorard, S., See, B. H. (2017). Non-cognitive impacts of Philosophy for Children. School of Education Durham University.

Scholl, R./Nichols, Kim/Burgh, Gilbert (2014). Transforming pedagogy through philosophical inquiry. In. International Journal of Pedagogies and Learning, 9/3, p. 253-272.

Scholl, Rosie/Nichols, K./Burgh, G. (2016). Connecting learning to the world beyond the classroom through collaborative philosophical inquiry. In. Asia-Pacific Journal of Teacher Education, 44/5, p. 436-454.

Topping, Keith J./Trickey, Steve (2007). Collaborative Philosophical Enquiry for School children. Participant Evaluation at 11 Years, in. Thinking. The Journal of Philosophy for Children 18/3, p. 23-34.

received in: 17.05.2019

accepted in: 03.06.2019 